\title{
Reproductive biology of the Endangered white-spotted sand bass Paralabrax albomaculatus endemic to the Galapagos Islands
}

\author{
P. Salinas-de-León ${ }^{1, *}$, A. Bertolotti ${ }^{1,2}$, C. Chong-Montenegro ${ }^{1}$, M. Gomes-Do-Régo ${ }^{3}$, \\ R. F. Preziosi ${ }^{4}$ \\ ${ }^{1}$ Department of Marine Sciences, Charles Darwin Research Station, Av Charles Darwin s/n, Puerto Ayora, Santa Cruz, \\ Galapagos Islands, Ecuador \\ ${ }^{2}$ School of Biological Sciences, University of Aberdeen, Aberdeen AB24 2TZ, UK \\ ${ }^{3}$ Departamento de Morfología e Fisiologia Animal, Universiadae Federal Rural de Pernambuco, Recife, Brazil \\ ${ }^{4}$ Division of Biology and Conservation Ecology, Manchester Metropolitan University, Manchester M1 5GD, UK
}

\begin{abstract}
The white spotted sand bass Paralabrax albomaculatus is a member of the subfamily Serraninae and is endemic to the Galapagos Islands. Locally known as camotillo, it is an important component of the local artisanal fishery that is permitted in the Galapagos Marine Reserve. Despite its Endangered status on the IUCN Red List, and its local socio-economic importance, nothing is known about its life history. The reproductive biology of $P$. albomaculatus was studied from samples collected between February 2013 and March 2014. Histological examination confirmed functional gonochoristic sexual reproduction. Sex ratios were biased towards females (4.36:1), and although the size distribution of males and females overlapped, the mean \pm SD total length (TL) of males $(45.9 \pm 8.4 \mathrm{~cm})$ was significantly larger than that of females $(41.5 \pm 7.6 \mathrm{~cm})$. Length at first maturity for females was $37 \mathrm{~cm}$ TL. Monthly gonado-somatic indices and the presence of eggs in the hydrated sub-phase suggest a spawning season between October and March, with a reproductive peak between November and January. Given its restricted range and continuous levels of exploitation, a management plan that includes minimum and maximum landing sizes and a seasonal closure during the reproductive season is urgently required for this Endangered Galapagos endemic.
\end{abstract}

KEY WORDS: Camotillo $\cdot$ Serranidae $\cdot$ Small-scale fisheries $\cdot$ Galapagos Marine Reserve $\cdot$ MPA $\cdot$ Management

\section{INTRODUCTION}

The Serraninae, a subfamily of the Serranidae, are commercially important fishes commonly found in nearshore tropical, subtropical and temperate waters (Sadovy de Mithceson et al. 2013). This subfamily is represented by 3 genera and 7 species in the Galapagos Islands, Tropical Eastern Pacific (McCosker \& Rosenblatt 2010). Members of the subfamily Serraninae display complex sexual reproduction patterns (Sadovy \& Domeier 2005), including the formation of

*Corresponding author: pelayo.salinas@fcdarwin.org.ec reproductive spawning aggregations during specific seasons (Erisman \& Allen 2006, McKinzie et al. 2014). Understanding the reproductive biology of commercially exploited members of this subfamily is therefore key to informing fisheries management plans to avoid further overexploitation, as has already been reported in a number of species of the genus Paralabrax (Erisman et al. 2011, Sadovy de Mitcheson \& Erisman 2012).

The white-spotted sand bass Paralabrax albomaculatus, locally known as camotillo, is a member of the

() The authors 2017. Open Access under Creative Commons by Attribution Licence. Use, distribution and reproduction are unrestricted. Authors and original publication must be credited. 
Serraninae that is endemic to the Galapagos Islands (Pondella et al. 2003, McCosker \& Rosenblatt 2010). Camotillo is an important part of the Galapagos artisanal fishery, which involves $\sim 1200$ registered fishers and has operated since the 1920s (Reck 1983, Castrejón et al. 2014). Camotillo is a reef-associated species that inhabits rocky reefs and nearby sand patches to depths of over 200 m (Reck 1983). However, depth of occurrence varies with temperature, with preference for cooler water (Reck 1983). This species is therefore common in shallow reefs on the western parts of the islands of Fernandina, Isabela and Floreana, which are strongly influenced by the cold eastward-flowing Cromwell current (Palacios 2004). Camotillo is, however, most commonly found on deeper reefs and seamounts (>50 m) across the remainder of the archipelago (Reck 1983).

Members of the subfamily Serraninae display a diverse range of sexual patterns including gonochorism (separate sexes), simultaneous hermaphroditism and several forms of protogyny (female to male sex change) (Erisman et al. 2009, Erisman \& Hastings 2011). Difficulty in diagnosing sexual patterns in the genus Paralabrax have been previously documented, with some species like $P$. maculatofasciatus possibly exhibiting both protogyny and gonochorism (Sadovy $\&$ Domeier 2005). Aspects of spawning and reproduction for $P$. auroguttatus, $P$. clathratus, $P$. maculatofasciatus and $P$. nebulifer, which occur along the US west coast, have been subject to a considerable amount of research over the past decades. All of the above-mentioned Paralabrax species are now known to be functional gonochores with a non-functional bisexual juvenile phase, and clear separation of male and female tissues (Oda et al. 1993, Hovey et al. 2002, Sadovy \& Domeier 2005, Erisman \& Allen 2006). The minimum length at first sexual maturity for females of these 4 species ranges from 17.0$18.1 \mathrm{~cm}$, and the reproductive season occurs during the warm northern hemisphere summer months (May to September) (Oda et al. 1993, Hovey et al. 2002, Lowe et al. 2003, Erisman \& Allen 2006). $P$. clathratus has been documented to show aggregating behaviour during the reproductive season (Erisman \& Allen 2006). Despite an absence of basic life history information for $P$. albomaculatus, Reck (1983) suggested a reproductive season during the Galapagos warm season (October to January) based on monitoring of fishery landings. To date, no other information is available on the reproductive biology of $P$. albomaculatus.

Camotillo has been classified since 2010 as 'Endangered' by the International Union for the Conserva- tion of Nature (IUCN) due to its restricted range, and based on a $70 \%$ decline in population abundance, which was inferred from a dramatic decline in fishery landings despite a continued increase in fishing effort between 1998 and 2001 (Robertson et al. 2010). Notwithstanding its threatened status, we still have no information on the most basic life history characteristics for camotillo, such as reproductive strategy, reproductive season, growth rates or longevity. Considering that, at present, camotillo continues to be an important artisanal fishery within the Galapagos Marine Reserve (GMR), it is imperative to develop studies that determine its basic life history information in order to provide the best scientific knowledge so as to inform a management plan for this species.

The aim of this study was therefore to provide the first information on the reproductive biology of $P$. albomaculatus. Specific objectives were to (1) determine reproductive strategy, (2) characterize size frequency distributions by sex, (3) estimate female length at first sexual maturity, (4) determine spawning season, and (5) quantify total female fecundity.

\section{MATERIALS AND METHODS}

\section{Study location and collection of specimens}

This study was conducted in the GMR, located $1000 \mathrm{~km}$ from mainland Ecuador, South America (Fig. 1). All fish used in the present study were captured by Galapagos registered artisanal fishers using hooks and lines at different sites in the central, southern and western part of the GMR (Fig. 1).

A total of 719 camotillo were obtained during trips aboard fishing boats or from the local fish market of the Island of Santa Cruz from February 2013 to March 2014. Collections were made on a weekly basis. Time, date, location and total length (TL) to the nearest $\mathrm{cm}$ of each individual fish were recorded. When fish were landed whole, total body mass $\left(\mathrm{M}_{\mathrm{T}}\right)$ was recorded to the nearest gram. When available, gonads were extracted from individuals, and wet mass of gonads $\left(\mathrm{M}_{\mathrm{G}}\right)$ was recorded to the nearest $0.01 \mathrm{~g}$.

\section{Histological analysis}

Fish that were landed whole were sexed by macroscopic inspection of gonads. From these, a subsample of gonads was removed, weighed to the nearest $0.01 \mathrm{~g}$, and 3 small $3-6 \mathrm{~mm}$ tissue sections $(\sim 0.5 \mathrm{~g})$ of the anterior, central and posterior portions of the 


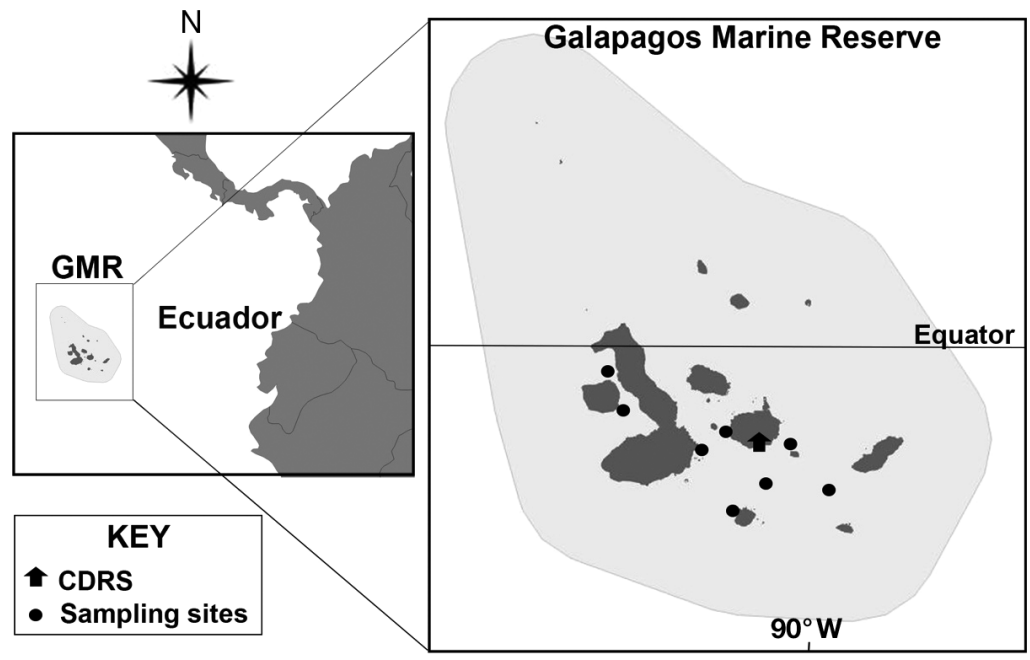

Fig. 1. Location of sampling sites for Paralabrax albomaculatus in the Galapagos Marine Reserve (GMR). Map shows the location of the Charles Darwin Research Station (CDRS) on the Island of Santa Cruz by an unpaired $t$-test in the statistical package Minitab v15.

\section{Spawning season}

The gonado-somatic index $\left(\mathrm{I}_{\mathrm{G}}\right)$ of each fish was calculated according to the formula: $\mathrm{I}_{\mathrm{G}}=\mathrm{M}_{\mathrm{G}} / \mathrm{M}_{\mathrm{T}}$. The timing and duration of the spawning season was determined by plotting the $\mathrm{I}_{\mathrm{G}}$ and the number of individuals in each of the different gonadal classifications by month throughout a calendar year (February 2013 to January 2014). Additionally, Fulton's condition factor $(K)$ of each fish was calculated using the formula: $K=100$ (Weight $/$ Length $^{3}$ ). $K$ was also plotted against sampling months.

\section{Total female fecundity}

Female gonads that showed clearly visible hydrated eggs were weighed to the nearest $0.01 \mathrm{~g}$ and placed in modified Gilson's fluid to free and harden the eggs for examination (DeMartini 1987). Each pair of preserved ovaries was blotted dry and reweighed to the nearest $0.01 \mathrm{~g}$. Three small sections $(0.03-$ $0.06 \mathrm{~g}$ ) from the anterior, central and posterior part of both lobes were then used for immediate microscopic examination. Batch fecundity was estimated from the mean number of hydrated eggs recorded in the 3 weighed subsamples, with subsample counts representing the error of the estimate (DeMartini 1987).

\section{RESULTS}

A total of 547 camotillo out of the total 719 measured during this study could be sexed by macroscopic inspection of gonads. The gonads of 281 of these fish, ranging between 25 and $64 \mathrm{~cm}$ (TL), were analysed following histological procedures. The gonads of 6 females, ranging between 29 and $50 \mathrm{~cm}$ (TL), in the hydrated stage were used for estimation of total fecundity.

\section{Reproductive strategy}

The gonads of 281 fish were sexed by microscopic analysis. Given the small number of male 
fish ( $\mathrm{n}=31$ ) examined histologically, here we only describe female sexual stages. The morphology of Paralabrax albomaculatus gonads has the same characteristics as other species of the genus $\mathrm{Pa}$ ralabrax, with 2 lobes attached posteriorly with oocytes contained within a lamella that enters the ovarian lumen, as described by Sadovy \& Domeier (2005).

No transitional individuals were found. Bisexual individuals with both tissues present could not be identified as transitional since it was not possible to differentiate between growing and degrading tissue. Two females had testicular tissue or presumptive testicular tissue present in their gonads. The presumptive testicular tissue was identified using the description provided by Sadovy \& Domeier (2005) where it occurs in the same location as the testicular tissue observed in other females.

Histological preparations of female gonads (Fig. 2) were classified into 5 different stages following the criteria established by Brown-Peterson et al. (2011) (Table 1).

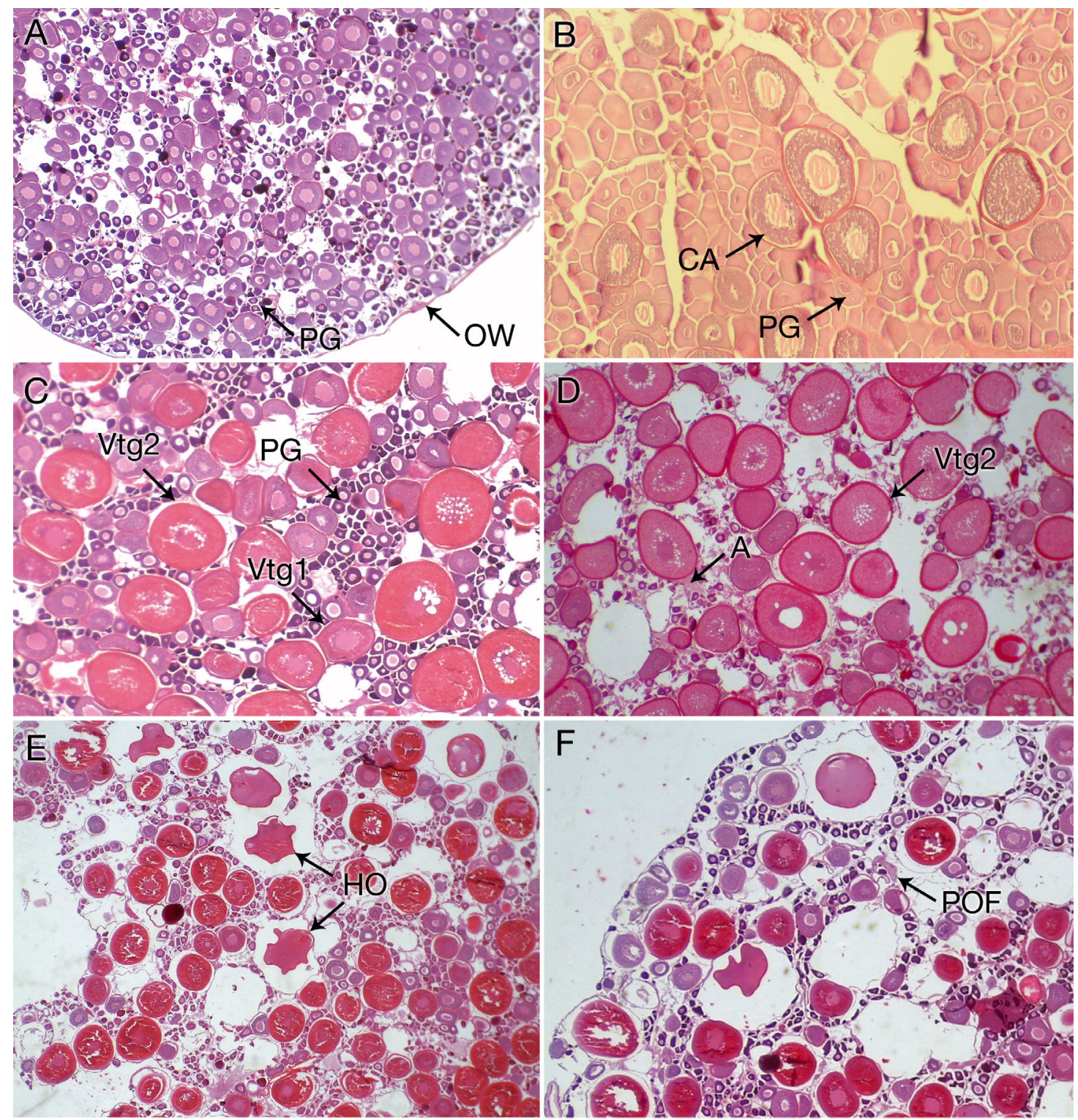

Fig. 2. Gonadal development stages for immature and mature female Paralabrax albomaculatus in the Galapagos Marine Reserve. (A) Immature, (B) mature inactive, (C) mature developing, (D) mature developing, (E) spawning capable, (F) regressing. OW: ovarian wall; PG: primary growth; CA: cortical alveola; Vtg1 (Vtg2): vitellogenic stage 1 (stage 2); A: atresia; HO: hydrated oocyte; POF: post-ovulatory follicle 
Table 1. Microscopic description of reproductive development stages of Paralabrax albomaculatus female gonads in the Galapagos Marine Reserve

\begin{tabular}{|ll}
\hline Stage & Microscopic description \\
\hline Immature & $\begin{array}{l}\text { Small ovaries and very thin gonadal wall. Lamellae dominated entirely by primary growth stage } \\
\text { oocytes tightly congregated. No evidence of previous spawning, no atresic bodies and no muscle } \\
\text { bundles. }\end{array}$ \\
Mature inactive & $\begin{array}{l}\text { Large ovaries with a thicker gonadal wall. Lamellae covered in primary growth stage oocytes } \\
\text { and cortical alveolar oocytes. High proportion of vitellogenic oocytes in vesicular growth. Evidence } \\
\text { of previous spawning due to the presence of muscle bundles and enlarged blood vessels within } \\
\text { lamellae. }\end{array}$ \\
Mature developing & $\begin{array}{l}\text { Thinning gonadal wall, occurrence of oocytes in primary growth stage and cortical alveolar oocytes } \\
\text { within lamellae. Numerous early stage vitellogenic oocytes (stages 1 and 2). Atresic bodies could be } \\
\text { present. } \\
\text { Thin gonadal wall. Lamellae full of vitellogenic oocytes (stages 1 and 2), but also presence of oocytes } \\
\text { in further developed stages. Presence of hydrated oocytes or vesicular germinal migration that indi- } \\
\text { cates imminent spawning. Post-ovulatory follicles could indicate recent spawning. } \\
\text { Thickening gonadal wall, presence of intralaminar and cytoplasmatic filaments. Lamellae with pres- } \\
\text { ence of vitellogenic oocytes and oocytes in primary growth. Muscle bundle and of blood vessels. }\end{array}$ \\
\hline
\end{tabular}

\section{Population structure and sex ratio}

The TL of the fish sampled ranged from 25 to $64 \mathrm{~cm}$. From the subsample of fish that were sexed by histological analysis, we found that size ranges for both males and females overlapped (Fig. 3), although the mean \pm SD size of males $(45.95 \pm 8.4 \mathrm{~cm} \mathrm{TL})$ was significantly larger than that of females $(41.47 \pm$ $7.6 \mathrm{~cm}$; unpaired $t$-test, $t=3.92 ; \mathrm{df}=304 ; \mathrm{p}<0.001$ ). The overall female to male sex ratio of the samples analysed was 4.36:1.

\section{Spawning season}

Analysis of $\mathrm{I}_{\mathrm{G}}$ values indicated that the spawning season occurred between the months of November and February (Fig. 4). Spawning-capable females were recorded throughout most of the year; however, females with hydrated eggs were only recorded from December through February (Fig. 5).

\section{Size at first maturity}

Only 5 immature females were recorded out of the 250 female gonads examined, and these corresponded to individuals between 25 and $36 \mathrm{~cm}$ TL. The length at which $100 \%$ female fish reach sexual maturity $\left(\mathrm{L}_{\mathrm{m}}\right)$ was determined to be $37 \mathrm{~cm}$ TL. An analysis using the length-frequency analysis wizard available in FishBase (www.fishbase.org) resulted in an $\mathrm{L}_{\mathrm{m}}$ of $37.1 \mathrm{~cm}$, a similar value to the results obtained by histological analysis.

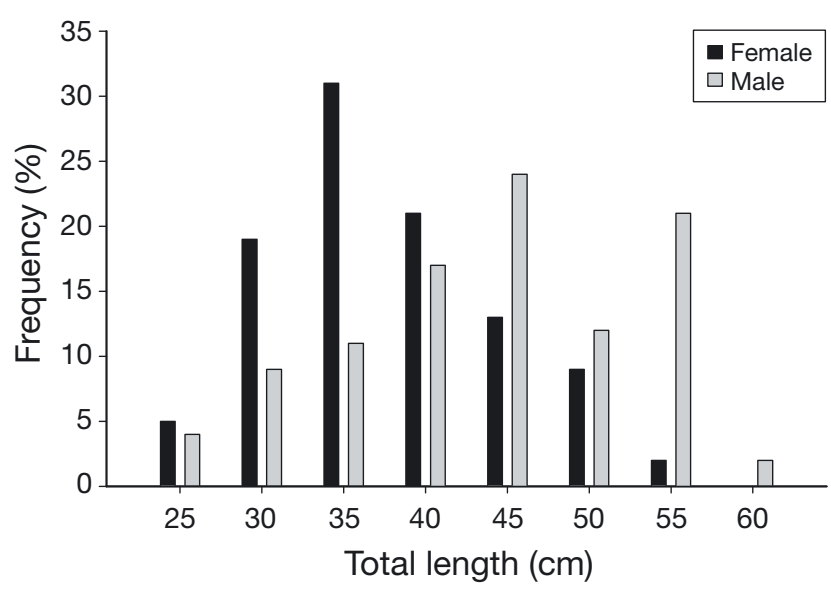

Fig. 3. Total length frequency distributions for female and male Paralabrax albomaculatus in the Galapagos Marine Reserve

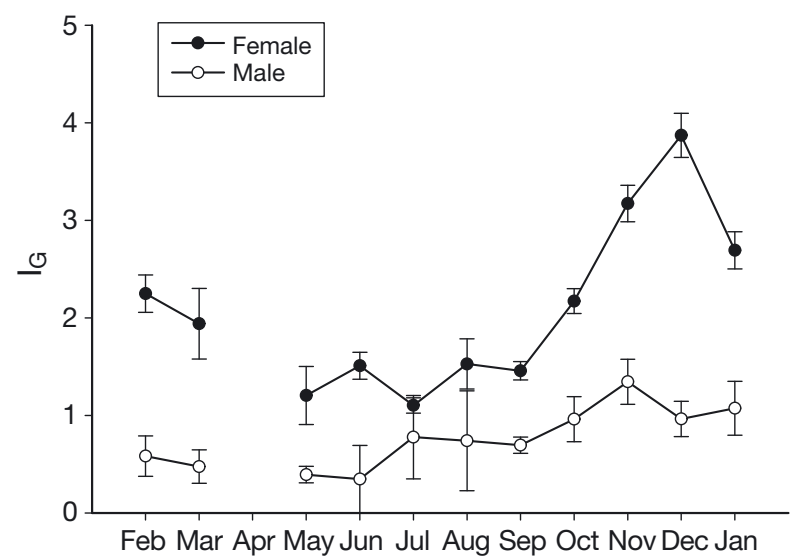

Fig. 4. Mean $( \pm \mathrm{SE})$ gonado-somatic index $\left(\mathrm{I}_{\mathrm{G}}\right)$ for female and male Paralabrax albomaculatus in the Galapagos Marine Reserve. No data available for April 

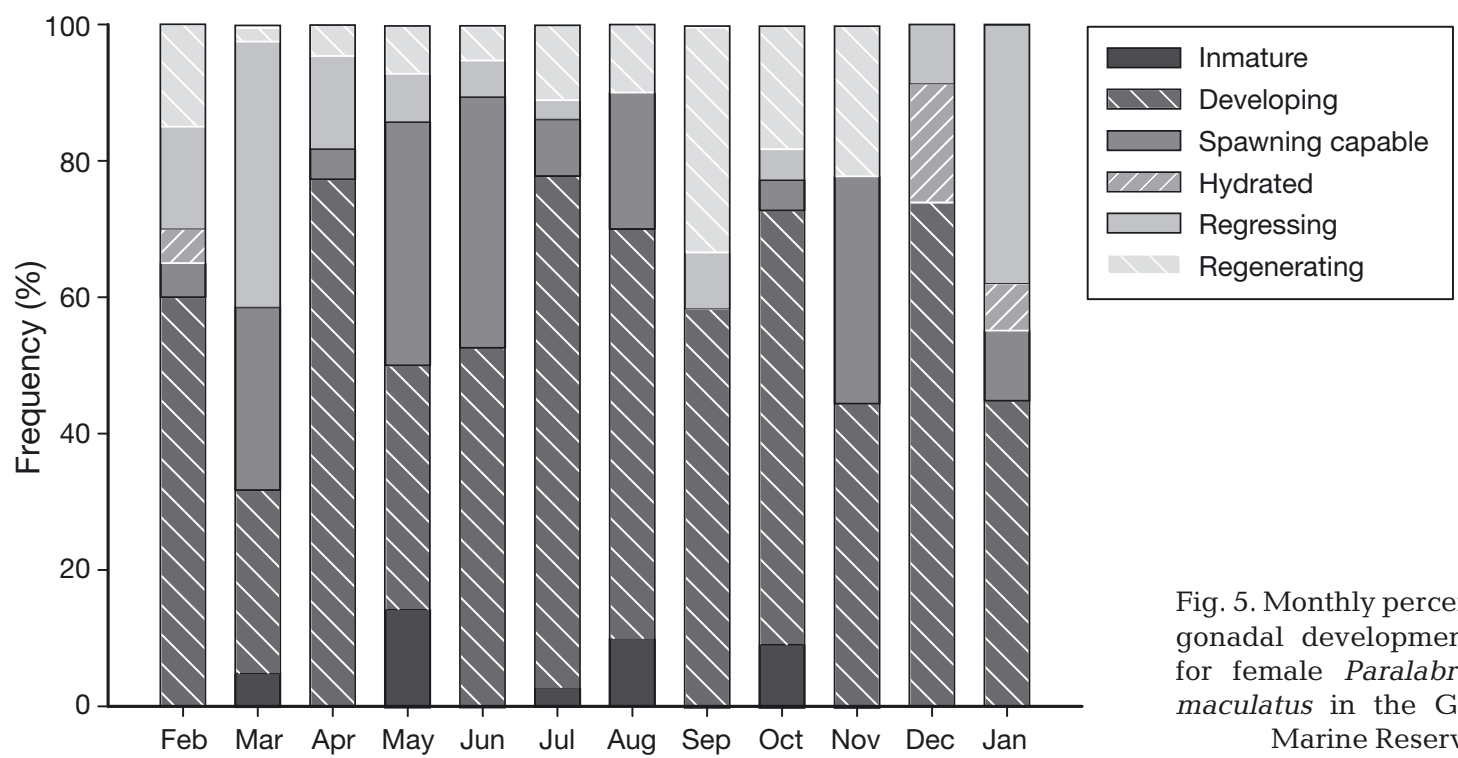

Fig. 5. Monthly percentages of gonadal development stages for female Paralabrax albomaculatus in the Galapagos Marine Reserve

\section{Total fecundity}

Total female egg production ranged from 23300 for a $29 \mathrm{~cm}$ TL individual to 542000 eggs recorded in a $50 \mathrm{~cm}$ TL specimen (Fig. 6).

\section{DISCUSSION}

\section{Reproductive strategy}

Of the 5 criteria proposed by Sadovy \& Shapiro (1987) to diagnose protogynous hermaphroditism, identifying the presence of transitional individuals is the strongest. Although in our study, no transitional individuals were positively identified, a few bisexual individuals were observed with healthy tissue of both sexes. However, ovarian tissue adjacent to testicular tissue within a gonad is not sufficient to diagnose a transitional individual. The small number of bisexual individuals reported in our study is expected, as these individuals tend to occur infrequently (Hovey et al. 2002).

Most male camotillo had an ovarian lumen in their testes, evidence of a past female stage (Hovey et al. 2002). However, some individuals show evidence of use of this lumen for sperm transport, which invalidates this hermaphroditism criterion, since only a nonfunctional gonadal lumen is an indicator of hermaphroditism (Sadovy \& Shapiro 1987). The great majority of males sampled in our study were also observed to have sperm sinuses within the gonadal wall. Two explanations other than hermaphroditism can account for the presence of these structures: (1) hermaphroditism was part of the ancestral past of comotillo and the structure has been preserved (Smith 1975), or (2) this species goes through a female-like juvenile stage in which these structures are present, and these are then preserved during growth and adulthood (Takahashi 1977).

The fourth criterion proposed by Sadovy \& Shapiro (1987) is the presence of atretic bodies in the male testis. A large proportion of the individuals sampled were found with these atretic bodies. However, it is important to note that these atretic bodies can be the result of many other cell processes (Roberts 1978), such as parasite encystation or degenerating sperm tissue (Hovey et al. 2002). If the atretic bodies are not clearly identified as atretic vitellogenic oocytes, then they provide weak evidence for hermaphroditism. In all camotillo individuals sampled in this study, no

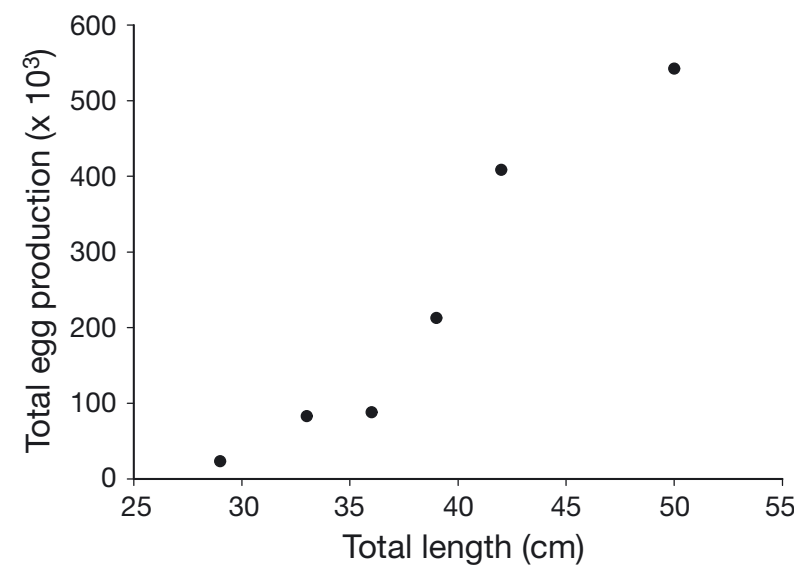

Fig. 6. Relationship between female total length $(\mathrm{cm})$ and total egg production for Paralabrax albomaculatus in the Galapagos Marine Reserve 
atretic bodies were clearly identified as vitellogenic oocytes. The presence of previtellogenic oocytes in male gonads can be interpreted in many different ways, such as exposure to high temperatures (Egami 1956), starvation (Egami 1955) and external exposure to hormones (Yamamoto 1969). A number of males were observed to have these features. However, this characteristic can only be used to complement others, as alone it provides weak evidence of sex reversal.

The fifth and last criterion used to diagnose protogynous hermaphroditism was population structure, in particular, age-frequency (or size-frequency when age data are not available) distribution and male to female sex ratios. It is thought that if a species is a protogynous hermaphrodite, females will be more abundant in the smaller size classes and males dominant in the larger size classes (Sadovy \& Shapiro 1987). In our study, although males tended to be, on average, larger than females, both sexes were represented in all size classes. This distribution is therefore suggestive of a gonochoristic strategy.

Taking into consideration all of these criteria, Paralabrax albomaculatus shows strong evidence of being a functional gonochore. It is possible that this species, like many others of the genus Paralabrax, goes through a bisexual juvenile stage, which would explain the presence of tissues of the opposite sex in both females and males (Hovey et al. 2002, Sadovy \& Domeier 2005). The presence of female features within the male testes of camotillo, such as sperm sinuses in the gonadal wall and a central gonadal lumen, do not provide strong evidence of hermaphroditism, as both structures are functional in males. They do, however, suggest that this species could be a secondary gonochore (ancestral hermaphrodite), but further phylogenetic studies are needed to confirm this diagnostic, since the most comprehensive phylogenetic analysis of the seabasses to date did not include $P$. albomaculatus (Sadovy \& Domeier 2005).

\section{Spawning season}

Both the $\mathrm{I}_{\mathrm{G}}$ and the histological analysis of female gonads suggest a marked seasonality in the reproductive behaviour of camotillo. A clear peak in the $\mathrm{I}_{\mathrm{G}}$ during the months of November and January was recorded. This coincides with the predicted reproductive season of the sailfin grouper Mycteroperca olfax, a member of the Serranidae that is endemic to the Tropical Eastern Pacific, which is also known to form spawning aggregations during the reproductive season (Rodríguez 1984, Coello \& Grimm 1993, Salinas-de-León et al. 2015, Usseglio et al. 2015). In addition to this, females with hydrated eggs were recorded only during this same period, which reinforces the notion that camotillo has a specific reproductive season. Future studies should examine the occurrence of spawning aggregations for camotillo, as these have been shown to occur in other species of the genus Paralabrax, such as a P. clathratus in California (Erisman \& Allen 2006).

\section{Size at first maturity}

A clear limitation of our study was the lack of small females $(<25 \mathrm{~cm} \mathrm{TL})$ in our samples, which prevented us from fitting a logistic maturation curve to our data to obtain an estimate of $\mathrm{L}_{50}$ for female camotillo. Despite the fact that we obtained over 700 individual fish both aboard fishing boats and at fish markets, we were unable to obtain small individuals. It is likely that juveniles are distributed in other habitats and/or bioregions of the archipelago and, consequently, are not taken in the fishery at present. Fishers have reported a higher abundance of juvenile camotillo around the western islands of Fernandina and Isabela, where the waters are significantly colder than the rest of the archipelago due to the influence of the Cromwell current. In this region, very small camotillo $(<10 \mathrm{~cm}$ TL) are occasionally observed in mangrove bays (P. Salinas-de-León pers. obs.). On the other hand, the lack of small camotillo may be a consequence of the fishing technique used, which could be excluding smaller individuals, as camotillo fishers mostly employ hand lines with 2 or 3 size 14 J-hooks.

Nevertheless, our results indicate that female size at maturation $\left(\mathrm{L}_{100}\right)$ is $37 \mathrm{~cm}$ TL. Despite $\mathrm{L}_{100}$ being a more conservative and precautionary approach for advising a size catch limit, we strongly recommend that it be adopted, given the restricted range of this species, its current Endangered status and the absence of any management strategy for this fishery.

\section{Total fecundity}

Our results for total fecundity in camotillo show a clear increase with female total length. These results are similar to those obtained for the barred sand bass $P$. nebulifer, where an exponential increase in total egg production was also reported (DeMartini 1987), 
and to those obtained in many other fish families (Hixon et al. 2014). Our results also add to the growing body of literature that highlight the importance of 'Big Old Fat Fecund Female Fish (BOFFFFs)' in maintaining stock productivity and stability, since these fish produce far more and often larger eggs that may develop into fitter larvae (Hixon et al. 2014).

\section{Management implications}

The GMR, as a World Natural Heritage Site with a multi-use marine reserve, should monitor the ecological impact of all of its activities and must ensure the sustainability of commercially valuable fisheries, especially when endemic species are involved. To date, none of the more than 50 commercially important fish species (Molina et al. 2004) for the 1200 Galapagos artisanal fishers has a species-specific management plan (Castrejón et al. 2014). There is growing scientific evidence that suggests a systematic over-exploitation of coastal resources in the GMR (Ruttenberg 2001, Hearn 2008, Burbano et al. 2014, Castrejón et al. 2014, Salinas-de-León et al. 2015, Schiller et al. 2015, Usseglio et al. 2015, Zimmerhackel et al. 2015). Our study provides the first scientific basis to implement a fisheries management plan for a Galapagos endemic whose IUCN threatened status equals that of some of the most iconic animals in the archipelago, such as the Galapagos penguin Spheniscus mendiculus and the flightless cormorant Phalacrocorax harrisi.

Our results suggest that establishing a minimum size of $35-37 \mathrm{~cm}$ TL would allow $95-100 \%$ of the females to spawn at least once, and therefore contribute to the reproductive output of the population before capture. Based on our total fecundity results, a $50 \mathrm{~cm}$ TL female camotillo produces over 20 times more eggs than a female half that size. BOFFFFs also produce better quality eggs that are more likely to survive the larval stage, and larger/older females tend to reproduce more times during the spawning season, thus contributing disproportionally more to the reproductive output of the population (Hixon et al. 2014). The implementation of a maximum capture size of $50 \mathrm{~cm}$ TL would allow larger, more fecund fish to spawn, thus enhancing reproductive output for the population.

Our results confirm that camotillo reproduce during the transition from the cold to the warm season in the Galapagos Islands, similarly to M. olfax (Rodríguez 1984, Coello \& Grimm 1993). This time of the year coincides with the peak of the 'pesca blanca' (white fish fishery), which targets several coastal fish species that are air-dried and exported to the mainland to be used as the main ingredient for Ecuador's traditional Easter soup, fanesca. A seasonal fishery closure during the reported peak reproductive season (November through January) would allow fish to spawn and perhaps protect possible spawning aggregations for camotillo, something which has already been reported for its congener Paralabrax clathratus elsewhere (Erisman \& Allen 2006) and $M$. olfax in the GMR (Salinas-de-León et al. 2015). Our research provides the necessary data to inform the implementation of a management plan for this endangered species in the GMR and highlights the importance of life-history studies for fisheries management in a UNESCO marine World Heritage Site.

Acknowledgements. We thank staff and volunteers at the Charles Darwin Research Station who contributed to fieldwork and sample processing. We are grateful to the Charles Darwin Foundation and Galapagos National Park Directorate for the institutional support for this study. We also thank the artisanal fishers of Galapagos for their help, and our special thanks go to Don Gabino and Don Nelson for their support and enthusiasm. This research was supported by grants from the Mohammed Bin Zayed Species Conservation Fund, The Lindblad National Geographic Conservation Fund and the Helmsley Charitable Trust. This publication is contribution number 2177 of the Charles Darwin Foundation for the Galapagos Islands.

\section{LITERATURE CITED}

Brown-Peterson NJ, Wyanski DM, Saborido-Rey F, Macewicz BJ, Lowerre-Barbieri SK (2011) A standardized terminology for describing reproductive development in fishes. Mar Coast Fish 3:52-70

Burbano DV, Mena CF, Guarderas P, Vinueza L, Reck G (2014) Shifting baselines in the Galapagos white fin fishery, using fisher's anecdotes to reassess fisheries management: the case of the Galapagos grouper. In: Denkinger J, Vinueza L (eds) The Galapagos Marine Reserve. Springer International Publishing, Cham, p 227-246

Castrejón M, Defeo O, Reck G, Charles A (2014) Fishery science in Galapagos: from a resource-focused to a social-ecological systems approach. In: Denkinger J, Vinueza L (eds) The Galapagos Marine Reserve. Springer International Publishing, Cham, p 159-185

Coello S, Grimm A (1993) The reproductive biology of $\mathrm{Myc}$ teroperca olfax (Jenyns) (Pisces: Serranidae): protogyny and breeding season. Rev Cienc Mar Limnol 3:115-128

DeMartini EE (1987) Tests of ovary subsampling options and preliminary estimates of batch fecundity for two Paralabrax species. Calif Coop Ocean Fish Invest Rep 28: $168-170$

Egami N (1955) Production of testis-ova in adult males of Oryziaslatipes. III. Testis-ovum production in starved males. J Fac Sci Univ Tokyo 7:421-428 
Egami N (1956) Production of testis-ova in adult males of Oryziaslatipes. VI. Effect on testis-ovum

production of exposure to high temperature. Annot Zool Jpn 29:11-18

Erisman BE, Allen LG (2006) Reproductive behaviour of a temperate serranid fish, Paralabrax clathratus (Girard), from Santa Catalina Island, California, USA. J Fish Biol 68:157-184

Erisman BE, Hastings PA (2011) Evolutionary transitions in the sexual patterns of fishes: insights from a phylogenetic analysis of the seabasses (Teleostei: Serranidae). Copeia 2011:357-364

Erisman BE, Craig MT, Hastings PA (2009) A phylogenetic test of the size-advantage model: evolutionary changes in mating behavior influence the loss of sex change in a fish lineage. Am Nat 174:E83-E99

Erisman BE, Allen LG, Claisse JT, Pondella DJ, Miller EF, Murray JH, Walters C (2011) The illusion of plenty: hyperstability masks collapses in two recreational fisheries that target fish spawning aggregations. Can J Fish Aquat Sci 68:1705-1716

* Hearn A (2008) The rocky path to sustainable fisheries management and conservation in the Galápagos Marine Reserve. Ocean Coast Manage 51:567-574

Hixon MA, Johnson DW, Sogard SM (2014) BOFFFFs: on the importance of conserving old-growth age structure in fishery populations. ICES J Mar Sci 71:2171-2185

Hovey CB, Allen LG, Hovey TE (2002) The reproductive pattern of barred sand bass (Paralabrax nebulifer) from southern California. Calif Coop Ocean Fish Invest Rep 43:174-181

Lowe CG, Topping DT, Cartamil DP, Papastamatiou YP (2003) Movement patterns, home range, and habitat utilization of adult kelp bass Paralabrax clathratus in a temperate no-take marine reserve. Mar Ecol Prog Ser 256: 205-216

McCosker JE, Rosenblatt RH (2010) The fishes of the Galápagos Archipelago: an update. Proc Calif Acad Sci 61: 167-195

McKinzie MK, Jarvis ET, Lowe CG (2014) Fine-scale horizontal and vertical movement of barred sand bass, Paralabrax nebulifer, during spawning and non-spawning seasons. Fish Res 150:66-75

McMillan DB (2007) Fish histology: female reproductive systems. Springer Verlag, Dordrecht

Molina L, Danulat E, Oviedo M, González JA (2004) Guía de especies de interés pesquero en la Reserva Marina de Galápagos Fundación Charles Darwin, Galápagos

Oda DL, Lavenberg RJ, Rounds JM (1993) Reproductive biology of three California species of Paralabrax (Pisces: Serranidae). Calif Coop Ocean Fish Invest Rep 34: 122-132

Palacios DM (2004) Seasonal patterns of sea-surface temperature and ocean color around the Galápagos: regional and local influences. Deep Sea Res II 51:43-57

Pondella DJ II, Craig MT, Franck JPC (2003) The phylogeny of Paralabrax (Perciformes: Serranidae) and allied taxa inferred from partial $16 \mathrm{~S}$ and $12 \mathrm{~S}$ mitochondrial ribosomal DNA sequences. Mol Phylogenet Evol 29:176-184

Editorial responsibility: Eduardo Martins, Vancouver, British Columbia, Canada
Reck G (1983) The coastal fisheries in the Galapagos Islands, Ecuador; description and consequences for management in the context of marine environmental protection and regional development. PhD dissertation, Christian-Albrechts-Universität, Kiel

Roberts RJ (ed) (1978) Fish pathology. Bailliere Tindall, London

Robertson R, Allen G, Dominici-Arosemena A, Edgar GJ, Rivera F, Merlen G (2010) Paralabrax albomaculatus. The IUCN Red List of Threatened Species. 2010.e. T183769A8173211. http://dx.doi.org/10.2305/IUCN.UK. 2010-3.RLTS.T183769A8173211.en (accessed 18 Oct 2017)

Rodríguez T (1984) Estudio preliminar para evaluar las características biológicas pesqueras de Mycteroperca olfax en las Islas Galápagos (Ecuador). Bol Cient Téc Inst Nac Pesca Guayaquil-Ecuador 6:3-66

Ruttenberg BI (2001) Effects of artisanal fishing on marine communities in the Galapagos Islands. Conserv Biol 15: 1691-1699

Sadovy Y, Domeier ML (2005) Perplexing problems of sexual patterns in the fish genus Paralabrax (Serranidae, Serraninae). J Zool (Lond) 267:121-133

Sadovy Y, Shapiro DY (1987) Criteria for the diagnosis of hermaphroditism in fishes. Copeia 1987:136-156

Sadovy de Mitcheson YS, Erisman B (2012) Fishery and biological implications of fishing spawning aggregations, and the social and economic importance of aggregating fishes. In: Sadovy de Mitcheson Y, Colin PL (eds) Reef fish spawning aggregations: biology, research and management. Springer Netherlands, Dordrecht, p 225-284

Sadovy de Mitcheson Y, Craig MT, Bertoncini AA, Carpenter KE and others (2013) Fishing groupers towards extinction: a global assessment of threats and extinction risks in a billion dollar fishery. Fish Fish 14:119-136

Salinas-de-León P, Rastoin E, Acuña-Marrero D (2015) First record of a spawning aggregation for the tropical eastern Pacific endemic grouper Mycteroperca olfax in the Galapagos Marine Reserve. J Fish Biol 87:179-186

Schiller L, Alava JJ, Grove J, Reck G, Pauly D (2015) The demise of Darwin's fishes: evidence of fishing down and illegal shark finning in the Galápagos Islands. Aquat Conserv 25:431-446

Smith CL (1975) The evolution of hermaphroditism in fishes. In: Reinboth R (ed) Intersexuality in the animal kingdom. Springer, Berlin, p 295-310

Takahashi H (1977) Juvenile hermaphroditism in the zebrafish, Brachydanio rerio. Bull Fac Fish Hokkaido Univ 28:57-65

Usseglio P, Friedlander AM, DeMartini EE, Schuhbauer A, Schemmel E, Salinas de Léon P (2015) Improved estimates of age, growth and reproduction for the regionally endemic Galapagos sailfin grouper Mycteroperca olfax (Jenyns, 1840). PeerJ 3:e1270

Yamamoto T (1969) Sex differentiation. In: Hoar WS, Randall DJ (eds) Fish physiology. III. Academic Press, New York, NY, p 117-175

Zimmerhackel JS, Schuhbauer AC, Usseglio P, Heel LC, Salinas-de-León P (2015) Catch, bycatch and discards of the Galapagos Marine Reserve small-scale handline fishery. PeerJ 3:e995

Submitted: April 10, 2017; Accepted: September 1, 2017 Proofs received from author(s): Ocotber 18, 2017 